\title{
O zmianie biernika w użyciach nieparadygmatycznych
}

Słow a kluc z e : podrodzaj żywotny; biernik; zmiana systemu Ke y w or d s : animate sub-gender; accusative; system change

Odziedziczony z praindoeuropejskiego system przypadków jest w języku polskim archaiczny i bardzo stabilny. W polszczyźnie zachowało się aż siedem (z ośmiu indoeuropejskich) przypadków i mają one w większości od setek lat niezmienione funkcje. Wyjątkiem jest biernik. Proces zmiany niektórych form biernika liczby pojedynczej rzeczowników męskich trwa od ponad tysiąca lat i w ostatnich latach nabrał szczególnego przyspieszenia.

W okresie prasłowiańskim i wczesnym staropolskim sytuacja była prosta. W rzeczownikach męskich biernik był zawsze równy mianownikowi: vidịo domb, $v l_{o}^{\prime} k b$, W następnych wiekach nazwy osób i zwierząt zmieniły formę biernika na równą dopełniaczowi, czego wynikiem stało się powstanie kategorii gramatycznej żywotności.

Kolejny etap, trwający kilkaset lat, to dołączanie do żywotnych rzeczowników o innym znaczeniu, na ogół całych kategorii semantycznych, jak grzyby czy nazwy jednostek monetarnych. Cały czas pojawiały się w klasie tak zwanych już żywotnych nowe wyrazy. Jeszcze pod koniec XIX w. zapalato się papieros, a Gombrowicz jeszcze grał w tenis. Zdanie kupiłem kwiatka 
usłyszałem po raz pierwszy w latach osiemdziesiątych XX w, a zdanie ale sobie sprawit samochoda! dopiero jakieś dwa lata temu.

Proces ten spowodował, że nazwa 'rzeczowniki żywotne' jest w obecnym stanie rozwoju polszczyzny właściwie już wyłącznie etykietą. Oprócz rzeczywiście żywotnych nazw zwierząt, należą do tej klasy jeszcze niektóre nazwy - również żywych - roślin i ich części, jednak tym razem dość niekonsekwentnie, jako że jest zjadłem banana, ale zasadziłem jałowiec. Poza tym jest ta klasa wyjątkowo heterogeniczna, obejmująca: zwierzęta (mam psa); antropomorficzne postacie mitologiczne (zobaczyl elfa, wierzy w Zeusa); kwiaty (kup tulipana); bakterie i wirusy (złapat gronkowca i krętka bladego); owoce i warzywa (zjadt orzecha, ugotowat pora); grzyby kapeluszowe (znalazt prawdziwka, kozaka i muchomora); figury i kolory w grach (zbit pionka, wyszedt w trefla); nazwy marek fabrycznych (kupit Volkswagena, sprzedat Singera, pali Camela); jednostki monetarne (dał mu dolara, jena, rubla i franka); planety i gwiazdy (lot na Marsa, Jowisza i Syriusza); fakultatywnie niektóre nazwy potraw (upiekt makowca, zjadt pqczka); tańce (tańczyć walca); nazwy męskiego narządu płciowego (ma małego penisa); nazwy rozgrywek sportowych lub części meczu (wygrać szlema, seta, gema); nazwy chorób (cierpi na Alzheimera, Parkinsona, ma raka, waglika, złapat syfa i trypra); inne (mieć pecha, nabić sobie guza, złapać bakcyla, wywinać kozła, zrobić fikołka, leczyć kaca, mieć fioła, palić papierosa, sptatać figla, przygotować sobie gotowca, mieć pierdolca, pietra, stanqć dęba, puścić baka).

W ostatnim czasie obserwujemy traktowanie jako żywotnych wszelkich wchodzących do słownika pożyczek $\mathrm{z}$ angielskiego, na pewno z obszaru komputery-telekomunikacja: ma i-poda, laptopa, smartfona, wysłat sms-a, maila, prowadzi bloga itp., ale być może zjawisko obejmuje już wszystkie anglicyzmy: trafił na drona, czyta Newsweeka i Timesa (co ciekawe czyta się Le Monde, być może dlatego, że to wyraz francuski, nie angielski).

Oprócz tego wyraźnie zarysowuje się tendencja możliwości wejścia do żywotnych każdego rzeczownika rodzaju męskiego, a na pewno tych, które mają w dopełniaczu -a, np. kup mi kwiatka; wyrwali mi zęba, więc mam doła. Niedawno pojawiły się charakterystyczne reklamy Mam smaka na Maka i Metoda na głoda. W ten sposób wytworzyła się sytuacja, że niektóre rzeczowniki męskie mogą mieć trzy odmienne formy dla mianownika, dopełniacza i biernika, np. smak czosnku, ta zupa jest bez smaku i mam na niego smaka. 
Do klasy tzw. żywotnych należą też nazwy gier, przy czym do niedawna wyłącznie mające w dopełniaczu końcówkę - $a$, a więc mówiło się gram $w$ tenisa, ale gram $w$ bilard. Teraz zaczęto mówić gram $w$ bilarda przy zachowaniu, choć niekonsekwentnym dopełniacza bilardu. Gra to, według definicji słownikowej, ,zabawa towarzyska prowadzona według pewnych zasad” oraz „rozgrywka prowadzona między zawodnikami lub zespołami według zasad określonych regulaminem danej dyscypliny" (por. SJPSzym). Nie wszystkie czynności mieszczące się w przytoczonej definicji nazywane są grami. O ile wszystkie konkurencje karciane, planszowe, z pionkami, bierkami itp. są tak nazywane, o tyle konkurencje sportowe tylko niektóre. Grą jest np. tenis, squash, rugby, siatkówka, piłka ręczna, badminton, krykiet, kręgle, bilard, golf a nie jest grą bieg przez płotki, rzut młotem, skok wzwyż, pływanie, boks, dżudo, zapasy. Jak się zdaje nie są nazywane grami konkurencje będące wyścigami, skokami, rzutami oraz dyscypliny należące do tzw. sportów walki. Z kolei gry to wszelkie konkurencje z użyciem piłek, lotek, kul, rakietek.

Ciekawą cechą rzeczowników męskich z podgrupy gier jest wytworzenie się w nich dwóch form biernika. Nie chodzi przy tym o wariancje fakultatywne jak w dnie/dni, patrzeć/patrzyć, Bieszczadów/Bieszczad, używanych całkowicie wymiennie, ale o dwie formy używane w odmiennych kontekstach i które nie zawsze mogą być wzajemnie podstawiane. Przykładem takiego rzeczownika jest tenis, mający w bierniku postać tenis i tenisa. Dowodem na to, że tenis ma dwa bierniki, nie zawsze wymienne, są zdania: Gram w tenisa oraz Lubię tenis. Forma tenisa w pierwszym zdaniu jest jedyną możliwą, podczas gdy w drugim (Lubię tenisa) jest możliwa, choć wyraźnie rzadsza.

Oto kilka przykładów, z prasy sportowej, pokazujących istnienie dwóch bierników w nazwach gier sportowych:

(1) Pasje piłkarzy: Grendel lubi tenis, Szeweluchin piłkę ręcznq.

(2) Andy Murray najbardziej lubi tenis Agnieszki Radwańskiej.

(3) Takie mecze Agnieszka Radwańska lubi najbardziej. ...przegra to szkoda i niech gra dalej a ja będę cieszyt się ogladajac jej tenis...

(4) Kiedy zaś schodzi na tenis, blokuje się i zamyka.

(5) Pogoda lubi tenis.

(6) Mam zupetnie inny tenis, kariere, idę wolniej, ale robie swoje, ciężko pracuję i mam nadzieję, że niedtugo znajdę się bliżej Agnieszki. 
(7) W finatowym starciu Kvitova zaprezentowała niesamowity tenis.

(8) Idę na tenis stołowy.

(9) Tak Kanada, lubi hokej, ale złotego medalu już chyba 50 lat nie zdobyta.

(10) Kto lubi hokej lub uprawiat ten sport już od małego.

(11) Kto lubi hokej na trawie?

(12) Patrzac na jego oparty na serwisowej przemocy tenis...

(13) Lubi ryż, ale kocha ping pong.

(14) Syn bardzo lubi tenis stołowy.

(15) Lubie poker, ale głównie live...

(16) Okazuje się, że sporo pitkarzy lubi tenisa.

(17) Jutro idę na tenisa, jak się ubrać na korty?

(18) Beata Ścibakówna na korcie. Lubi grać w tenisa.

\section{Konkluzja}

W języku polskim obserwujemy trzy następujące procesy:

1. Tendencja do całkowitej asemantyzacji kategorii żywotności.

2. Pojawienie się, po raz pierwszy w historii języków słowiańskich, rzeczowników męskich mających inny mianownik, dopełniacz i biernik.

3. Pojawienie się rzeczowników mających dwa różne bierniki, każdy używany w innych kontekstach.

Obserwujemy zatem obecnie zmianę in statu nascendi, jeszcze nieunormowaną, ale wyraźnie widoczną i bardzo szybko postępującą. Stanem wyjściowym jest istnienie czterech typów odmiany rzeczowników męskich w liczbie pojedynczej;

$\begin{array}{lllll} & \text { Typ 1 } & \text { Typ 2 } & \text { Typ 3 } & \text { Typ 4 } \\ \text { M. } & \text { dom } & \text { bat } & \text { kot } & \text { wót } \\ \text { D. domu } & \text { bata } & \text { kota } & \text { wotu } \\ \text { B. 1 dom } & \text { bat } & \text { kota } & \text { wotu }\end{array}$

Typ trzeci jest wyraźnie ekspansywny i wchodzi do niego coraz więcej rzeczowników, w tym wszystkie lub prawie wszystkie nowe pożyczki. Być może przejdą do niego z czasem wszystkie rzeczowniki typu 2. Typ 4. dotyczy tylko trzech rzeczowników: wołu, bawołu, piżmowołu. Jest on dziedzictwem 
prasłowiańskim i właściwie nigdy nie był produktywny, a w czasach ukształtowania się kategorii męskożywotności reprezentował go tylko jeden rzeczownik wolu; w historii polszczyzny typ się rozszerzył, obejmując jeszcze dwa rzeczowniki. Nie jest wykluczone, że typ ten, choć mikroskopijny, utrzyma się. Zmiany, które nastąpiły w ostatnich latach, spowodowały pojawienie się dwóch zupełnie nowych typów paradygmatu. Jeden z biernikiem różnym od mianownika i dopełniacza, drugi z dwoma biernikami, każdy występujący w innym kontekście.

\section{Typ $5 \quad$ Typ 6}
M. bilard
tenis
D. bilardu
tenisa
B. 1 bilarda
tenis
B. $2-$
tenisa

Oba powyższe typy są nie do końca zgodne z normą i regułami poprawnościowymi, ale są absolutnie powszechne, a przynajmniej bardzo częste. Przy czym, o ile forma bilarda bywa kwestionowana jako niepoprawna, o tyle chyba nikt nie ma zastrzeżeń ani do lubię tenis, ani do gram $w$ teni$s a$. A zatem rozdwojenie biernika na dwa przypadki jest już - przynajmniej u części użytkowników - faktem dokonanym.

Ponieważ dezintegracja biernika nie jest zmianą zakończoną, występuje w niektórych paradygmatach wariantywność morfologiczna, która przedstawia się jak niżej:
Typ 3a
Typ 4a
Typ 5a
Typ 6a
M. $z q b$
wót
bilard
tenis
D. $z e ̨ b a$
wotu a. woła
bilardu a. bilarda tenisa
B. 1 ząba. zęba wotu a. wota
bilard a. bilarda
tenis a. tenisa
B. 2
$-$
tenisa

Opisana tendencja powinna, jeżeli utrzyma się w najbliższym czasie, doprowadzić do bardzo znacznego powiększenia liczby rzeczowników należących do typu 3. i do ewentualnego wyjścia z użycia typu 4. Wygląda na to, 
że utrwali się też typ 6. z rozdwojonym biernikiem, który jak się zdaje występuje już u większości użytkowników języka polskiego. Wątpliwe jest natomiast przetrwanie typu 5. z trzema różnymi formami mianownika, dopełniacza i biernika.

Rzeczowniki z rozdwojonym biernikiem to przede wszystkim: tenis, hokej, krykiet, ping pong, poker i squash. Nie należą do nich - z niewiadomych powodów - cymbergaj, brydż i palant oraz - z oczywistych powodów (nazwy antropomorficzne) - chińczyk i dureń.

Rozdwojenie biernika w kilku nazwach gier jest zmianą sprzeczną z ogólną tendencją poszerzania klasy żywotnych. O ile pojawianie się bierników z końcówką - $a$ jest masowe, o tyle w tym przypadku mamy do czynienia z powrotem do formy biernika równej mianownikowi, bezkońcówkowej. Przyczyną tej zmiany jest być może podświadoma chęć uniknięcia frywolnego skojarzenia w zdaniach typu Małgosia lubi ogladać mojego tenisa i zastapienie go konstrukcją niepowodującą tego typu asocjacji lubi ogladać mój tenis. Oczywiście hipoteza ta jest nie do udowodnienia. Jest bowiem niemożliwe ustalenie, kto po raz pierwszy użył tej konstrukcji i jaka była podświadoma motywacja tego kogoś. Przyjmijmy zatem zasadę, że jeśli nie ma innej hipotezy, ta, która jest, powinna zostać zaakceptowana do czasu ewentualnego znalezienia (co mało prawdopodobne) czegoś lepiej tłumaczącego opisaną zmianę.

\section{Bibliografia}

Ampel-Rudolf M., 2009, Kategoria rodzaju gramatycznego i semantyczna kategoria istotności poznawczej, Linguistica Copernicana 2 (2), s. 209-221.

Lewiński P., 2006, Czy istnieje fleksja kulturowa?, Rozprawy Komisji Językowej XXIII, s. 139-145.

ŁaZIŃSki M., 2006, O paniach i panach. Polskie rzeczowniki tytularne i ich asymetria rodzajowo-ptciowa, Warszawa: Wydawnictwo Naukowe PWN.

NAGórko A., 1998, Zarys gramatyki polskiej (ze słowotwórstwem), Warszawa: Wydawnictwo Naukowe PWN.

SALONi Z., 1974, Klasyfikacja gramatyczna leksemów polskich, Język Polski LIV, z.1-2, s. 3-13, 93-101.

SJPSzym: Szymczak M. (red.), Słownik języka polskiego, t. 1-3, Warszawa: Państwowe Wydawnictwo Naukowe. 


\section{On the change of the accusative in non-paradigmatic uses}

\section{( s u m m a r y )}

In modern Polish we can observe some processes which contribute to a considerable system change which consists in the expansion of $-a$ in the accusative of semantically inanimate masculine nouns, the appearance of masculine names having different forms of nominative, genitive and accusative and - finally - the bifurcation of the accusative in two cases with reference to masculine nouns denoting games. 
